\title{
ASSESSING A B-LEARNING TEACHING APPROACH AND STUDENTS' LEARNING PREFERENCES IN HIGHER EDUCATION
}

\author{
Teresa Cardoso', Filomena Pestana ${ }^{2}$, João Aragão e Pina ${ }^{3}$ \\ ${ }^{1}$ Universidade Aberța, Open University Portugal; LE@D, Laboratório de Educação a \\ Distância e Elearning (PORTUGAL) \\ ${ }^{2}$ LE@D, Laboratório de Educação a Distância e Elearning, Universidade Aberta, Open \\ University Portugal (PORTUGAL) \\ ${ }^{3}$ ISCTE-IUL, Instituto Universitário de Lisboa (PORTUGAL)
}

\begin{abstract}
Aosiract
Distance learning has been gaining ground in I igher $\epsilon$ Jucation institutions, particularly in the context of blended learning, forcing institutions and te ${ }_{c}$ her to confront new challenges in the teaching / learning process [1] [2] [3] [4]. This trend has beon increasing in the world [5] [6], namely in the United States [1] [7] and in Europe [8] [9] [6] [10].

Blended learning, or simply b-learning, has bee 1 a, sor iated with the reduction of costs and efficiency [11] [3]. According to several authors, it enavies to combine face-to-face and online distance modalities (elearning or mlearning), so it is sair $u v e$ the better of both worlds [12] [13] [14]. It also allows to enhance greater space-time flexibility, anc when properly implemented allows the acquisition of meaningful learning, centered on student autonomy, which, among other aspects, takes into account different learning styles/preferences.
\end{abstract}

Therefore, blended-learning can inspire course univulum design, including updating former face-toface pedagogical offers in order to meet the ble Ind $^{\prime}$ or hybrid principles and delivery. Bearing in mind this teaching / learning specific scenario, we develnr $d$ two surveys to assess such a new teaching approach and the students' preferences, in two uifferent moments - at the beginning and at the end of a higher education unit course. Hence, in this text, we will present those surveys, as well as their theoretical and methodological framework. Botr surveys have already been validated and tested, and preliminary data analysis is being developed.

We expect this pedagogical approach can cont.".uiv , sustain the assessment of teaching practices towards students' learning preferences, and th, choice of adequate technologies to fit those preferences. Ultimately, we expect the results $\mathrm{C}_{u} . . . \mathrm{u}$..u light for further research, so as to improve the development of blended-learning course curricu:...........ign in higher education.

Keywords: Blended-learning, Higher Education, r e c inıng, Students' learning preferences, Survey.

\section{INTRODUCTION}

Distance learning has been gaining ground in r....... ducation institutions, particularly in the context of blended learning, forcing institutions and $t \in$ zcrers to confront new challenges in the teaching / learning process [1] [2] [3] [4]. This trend has be en ncl zasing in the world [5] [6], namely in the United States [1] [7] and in Europe [8] [9] [6] [10].

Blended learning, or simply b-learning, has bee 1 a: sociated with the reduction of costs and efficiency [11] [3]. According to several authors, it en thls c to combine face-to-face and online distance modalities (elearning or mlearning), so it is said tn be the better of both worlds [12] [13] [14]. It also allows to enhance greater space-time flexibility, anc when properly implemented allows the acquisition of meaningful learning, centered on student $\cdots \cdots \cdots n y$, which, among other aspects, takes into account different learning styles/preferences.

However, the definition of the concept of blended learning is not consensual, emerging, in a broad sense, as a dynamic process that is often organic and context-specific [15]. Following the perspective of several other authors, we can quote [16], for whom "blended learning is the effective combination of different modes of delivery, models of teaching and styles of learning". [5], [17] and [18] also highlight the learning styles. In the words of [19] it is associated with "a pedagogy that places the primary responsibility of learning in the student". For [20], "Blending is an art that has been practiced by inspirational teachers for centuries" and that "adds extra dimensions to learning". 
As [20] or [10] recognize, the concept can combine face-to-face sessions with remote sessions or only remote sessions. But for [21], "it represents much more than the integration of in-presence and nonpresence moments [...] it must be understood as a dynamic strategy that involves different approaches and pedagogical models, different technologies and different learning spaces (formal and nonformal)". For these authors, blended learning can also be accomplished only with distance sessions, in this case, in what they call blended (e)learning.

For [22], the concept integrates still another feature, thus, "blended learning is the mix of learning material such as face-to-face, online, technologies and print bases that allow the students to be engaged with the content of course". [23] state that, with this modality, the "students gain access and flexibility with regard to at least one of the following dimensions: time, place, pace, learning style, content, assessment or learning path".

Therefore, blended-learning can inspire course chuivuir a design, including updating former face-toface pedagogical offers in order to meet the blended,$r$ hybrid principles and delivery. Bearing in mind this teaching / learning specific scenario, we devtiuncu iwo surveys to assess such a new teaching approach and the students' preferences, in two diffr. EII noments - at the beginning and at the end of a higher education unit course. Hence, in the follov ing ser tion, we will present those surveys.

\section{METHODOLOGY}

Our research is aimed at assessing a b-learni ig ear hing approach and the students' learning preferences in higher education within this hybrid „.lociality, namely (and at this initial phase) in the curricular unit "Professional Presentations". This u' iuular unit was delivered at the ISCTE-IUL (Portugal), "a public university established in 19: 2" 24]. Moreover, in the second semester of the 2018/2019 academic year, it was delivered for the ursı unne in blended learning, by a different team of teachers, in different graduation/post-graduation pi sgr am .

For that purpose, and bearing in mind that t_........./learning specific scenario, as previously mentioned, we developed two surveys, as also sai ' + n assess such a new teaching approach and the students' preferences, in two different moments - at the Jeginning and at the end of that unit course. We support the development of those surveys in a set of studies in which it was sought to identify similar topics.

As a prior remark, it is important to mention that $m$ anı ctı idies relate the satisfaction of a course in the modality of blended learning to the final grades s udents obtain, at the end of their formal learning / curricular path, in a given course unit/program [25] $\ldots . .$.

"Results from the comparison studies sur.,yest generally that online courses are at least comparable to classroom-based courses in achieving desired learning outcomes, while there is divergence in findings of comparisons ot other course aspects. Collectively, the range of untested conceptual frameworks, the lar. $\therefore$ uiscipline-specific theories, and the relative absence of a critical mass of researchers $f$ ) $\mathrm{cu}$;ed on the topic suggest ample opportunities for [...] scholars seeking to enter this research community"

Hence, we assumed as a major goal in our study o c stribute to fill the existing gap in the b-learning research domain (cf. the absence referred to in th vivviuus paragraph), centering our surveys in two main topics, i.e. assessing both the teaching/learn' $\mathrm{ng}$ no lality and the students' learning preferences. In this text, we will present only the common que stic 15 n the two surveys that we have developed, with regard to those two topics (see Figure 1 arıu rigure 2 represented afterwards, in which the questions of the survey 2 are highlighted in bolc',. 'vul surveys have already been validated and tested.

Survey 1 (S01) and Survey 2 (S02) also have in common the informed consent for participating in the study, as well as the characterization of the stude its' profile (e.g. age and program in which they are enrolled in). On the contrary, surveys 1 and 2 diff. ........ total amount of questions (27 in the former and 19 in the latter). This difference in the number of questions (Q) can be explained by the fact that some aspects are only possible to be accessed before the implementation of a certain pedagogical strategy or approach, as was the case in the delivering of the "Professional Presentations" unit. For instance, it only made sense to question the students about a prior learning experience in the blended learning modality at the beginning of the unit course (UC) - S01\#Q09. Excluding the UC of Professional Presentations that you are now going to attend, how many courses or curricular units 
have you already attended in the b-learning mode? This is an example of a closed-ended question, the majority in both surveys. Nevertheless, we did also considered open-ended questions.

S01\#Q10. How many hours do you expect to dedicate to this Unit Course (UC), excluding the face-to-face classes?

S02\#Q10. How many hours have you dedicated to this Unit Course (UC), excluding the face-to-face classes?

S01\#Q11. The introduction of the b-learning component in this UC, what main advantages can it bring to you?

S02\#Q11. The introduction of the b-learning component in this UC, what main advantages did it bring to you?

:

1\#Q12. The introduction of the b-learning component in this UC, what main disadvantages can it bring to you?

S02\#Q12. The introduction of the b learning component in this UC, what main disadvantages did it bring to you?

•

S01\#Q13. What percentage of content do you expect to be made avail>', e online?

S02\#Q13. What percentage of content was made available online

○ $0 \%$ O 1 a $29 \% \quad$ O 30 a $79 \% \quad$ O $80 \%$ ou mais

S01\#Q14. Among the aspects listed below, select the one that you consider to be the greatest benefit of a UC in blearning. Choose only one answer.

S02\#Q14. Among the aspects listed below, select the one that you consider to be the greatest benefit of a UC in blearning. Choose only one answer.

O Provide alternative learning opportunities

O Offer distance learning to a large number of individuals.

O Promote more student involvement.

Contribute to increasing the academic performance.

O Contribute to increase the size of the classroom.

Decrease costs.

O Other:

S01\#Q16. Please indicate your level of agreement with the following statements.

S02\#Q16. Please indicate your level of agreement with the following statements.

Us , the scale between 1 (Totally Disagree) to 7 (Totally Agree)

A program/course in b-learning...

... is a dynamic modality of teaching-learning. is a more effective teachin r earning modality.

... is a more efficient te $>$. Ing-learning modality. is a more demanding teacruns-rearning modality. invol..............nt technologies.

. involves different +oachinm methodologies. involves $d$ ifert it spaces of learning. combines face-to-face and 1 on- $f$ ce-to-face moments. increases the interaction between teacher and student. ... incre i ses tudent collaboration. increases the wor load for the student. increases the workload for the teacher. increases the workload for both th : stı lent and the teacher. ence ura! ss al tonomous work. encourages collaborative work. combines synchronous and asynchronous $\mathrm{mr} \ldots \mathrm{\gamma}^{+} \ldots$... communication. enables to manage the time to $p$ rfor, the tasks of the UC. enables to choose the space where I p . . . tasks of the CU. ... has more credibility than if it was dalinered in other formats. is more advantageous than if it was eliv red in other formats.

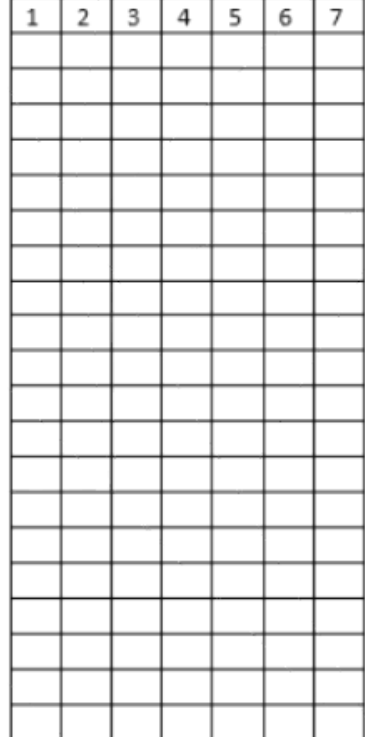

Figure 1. Questions on the teaching/learning modality (S01 and S02). 


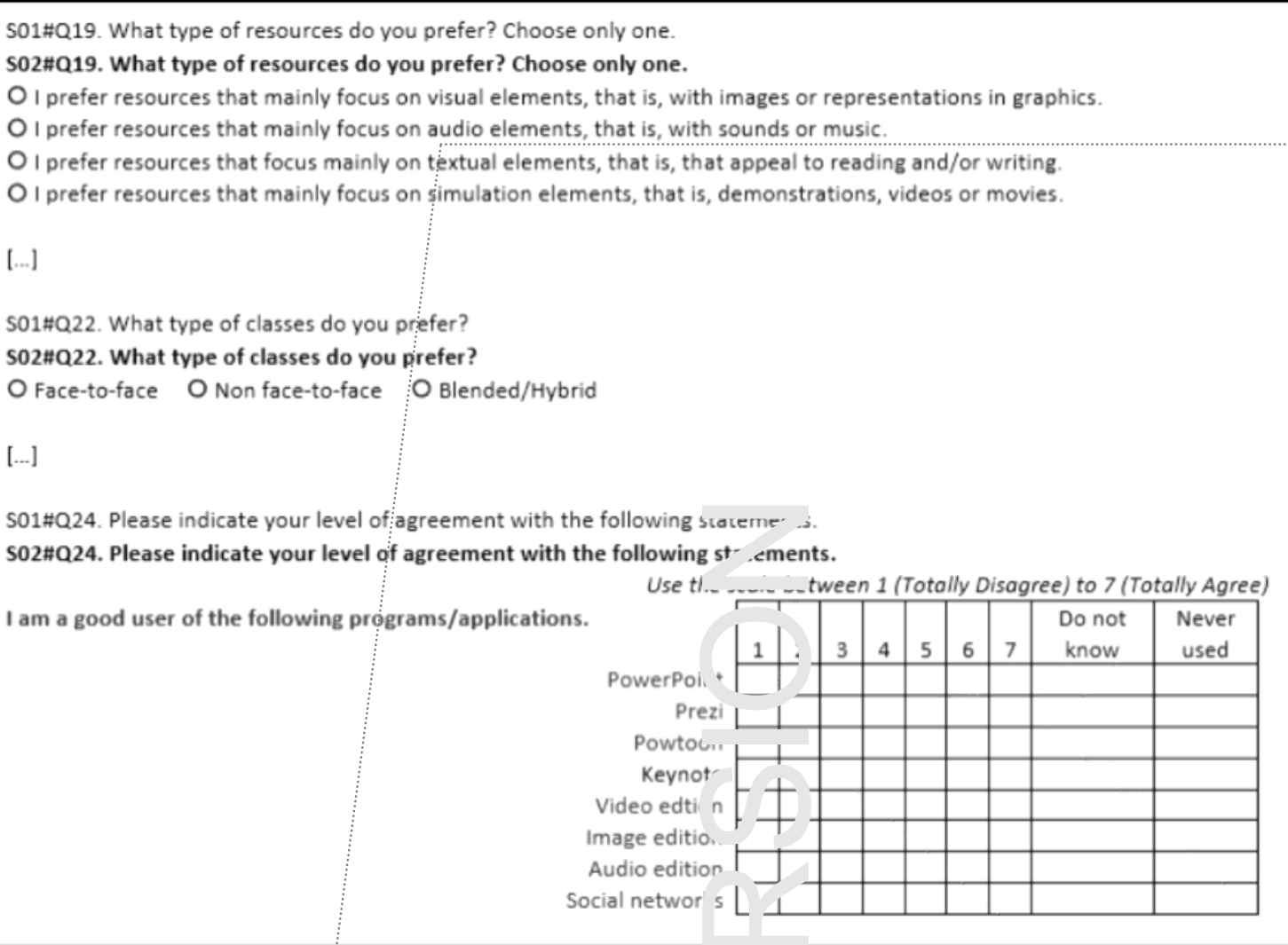

Figure 2. Questions on the learning / ref sel ces (S01 and S02).

\section{RESULTS}

Since the unit course is being offered as an intensive $m$ uulle, with a different calendar, according to the different programs involved, we are still implementing the surveys, to students of different classes. Therefore, we are still in the process of collecting anc' organizing data. However, we have already started a preliminary data analysis that will ultimately ell $\therefore$....... the following topics, among others: the assessment of the degree of familiarity with the blenced-learning modality, the assessment of the degree of satisfaction with the blended-learning moually he understanding of what motivates students in their individual learning process, and the under sanding of what motivates students in their collaborative learning process. We intend to compare these unvics within the students of a same class, and between students of the different classes enrollcu, "' iwo different moments, as previously mentioned, in the beginning and at the end of the $u^{r} . . r$ z. $r$ se. These comparisons will certainly provide important contributions for the development of $1 \mathrm{k}$ y research area, as blended learning has come to be considered as a didactic response that inuw he needs that the new paradigms in education demand.

\section{CONCLUSIONS}

In this text, we have presented an overview of the $\mathrm{cl}^{\mathrm{m} n} \mathrm{int}^{\mathrm{n}}$ of blended learning, which we will be further analysing in the future. Then, we focused on the ecsenre of a survey specifically developed to assess a b-learning teaching approach implemented for the first time in a graduation and postgraduation unit course, and the students' learning preinrr $\mathrm{nmns}$, in higher education. The survey is theoretically framed by a state-of-the-art, which is in +. rn based on a knowledge mapping and synthesis on the blended learning concept and its princ iple 3 , in different scientific fields. This feature will make it possible to further compare the results in t... _ _.....ing future among students of different scientific course programs.

The survey is meant to be applied at the beginning and the end of that (or any other) unit course delivered in the blended learning modality. Thus, in fact, it is materialized in two surveys, to be applied in those two distinct moments, namely, as we recall, at the start and at the end of a given b-learning curricular path. 
As an anticipation of the data analysis withdrawn from the obtained results, still an ongoing process, we expect that the introduction of this b-learning pedagogical approach in the unit course of "Professional Presentations" can contribute to sustain the assessment of teaching practices towards students' learning preferences, and the choice of adequate technologies to fit those preferences, not only in ISCTE-IUL but also in other university institutions. Ultimately, we expect the results can shed light for further research, so as to improve the development of blended-learning course curriculum design in (higher) education.

\section{ACKNOWLEDGEMENTS}

Mobile Learning in Higher Education (MINE) Project 2016-1-AT01-KA203-016784.

Pro-rector for Pedagogical Innovation and Elearning, Open University Portugal.

\section{REFERENCES}

[1] T. Crews, J. Butterfield. Data for Flipped Classroom De;rgn: Using Student Feedback to Identify the Best Components from Online and Face-to-Face Ziuuus. Higher Education Studies, 4(3), 38-47, 2014. DOI:10.5539/hes.v4n3p38

[2] R. Garrison, H. Kanuka. Blended Learning: Uncover, g Its 7 ransformative Potential in Higher Education. The Internet and Higher Education 7(2), 95- ı vo, 2004. DOI: 10.1016/j.iheduc.2004.02.001

[3] D. Thurab-Nkhosi. Implementing a Blended/Online L sar inç Policy on a Face-to-Face Campus: Perspectives of Administrators and Implications for C' '. ncer. Journal of Learning for Development, 5(2), 133-147, 2018.

[4] T. Weldy. Traditional, Blended, or Online: Business : ituc ent Preferences and Experience with Different Course Formats. E-Journal of Business Education and Scholarship of Teaching, 12(2), 55-62. ISSN: EISSN-1835-9132, 2018.

[5] J. Arbaugh, M. Godfrey, M. Johnson, B. Pollack, B. Ivier uuvi i, W. Wresch (2009). Research in online and blended learning in the business disciplint. Key findings and possible future directions. Internet and Higher Education, 12, 71-87, 20ก^. DOI:10.1016/j.iheduc.2009.06.006

[6] A. Hilliard. Global Blended Learning Practices for Teaching and Learning, Leadership and Professional Development. Journal of International E ducation Research, 11(3), 179-188, 2015. ISSN-2158-0979

[7] L. Gurley. Educators' Preparation to Teach, Perceived Teaching Presence, and Perceived Teaching Presence Behaviors in Blended and Online Le-. ning Environments. Online Learning, 22(2), 2018. DOI:10.24059/olj.v22i2.1255

[8] F. Arcos, P. Ortega. Building a Framework for an Enyinor Language Course in an LMS with SCORM Compliant Learning Objects and Activities. 1. _ zarinis, S. Green, H. Pearson, Handbook of Reasearch on E-learning Standards ar $x$ Ir teroperability: Frameworks and Issues, 228-245, 2011. United States of America: IGI Global.

[9] J. Fernandes. Definição do conceito de blended lear ins. . Proposta metodológica no quadro da terminologia de base conceptual. Tese de Doutoram ant .. ᄃSSH - Universidade Nova de Lisboa, 2015.

[10] P. Peres. O blended-learning no contexto português do Ens ino Superior: uma visão geral. Indagatio Didactica, 10(2), 297-316, 2018. ISSN: 1647-3582.

[11] I. Pereira, A. Figueiredo. Um contexto de aprendizac em promotor da participação dos alunos do ensino superior. Atas do SIIE 09 - XI Simpósio In ‘u ..uviunal de Informática Educativa, 2009.

[12] S. Feng. Applied Research on College Sports Blend $d \mathrm{l}$ earning Based on Moodle Platform. Educational Sciences: Theory \& Practice, 18(5), $107>1$ 1 262018. DOI:10.12738/estp.2018.5.010

[13] D. Otto. Using Virtual Mobility and Digital Storytelling in Blended Learning: Analysing Students' Experiences. Turkish Online Journal of Distance Education, 19(4), 90-103, 2018. 
[14] M. Vaughan, D. Garrison. Creating cognitive presence in a blended faculty development community. Internet and Higher Education, (1), 1-12, 2005. DOI:10.1016/j.iheduc.2004.11.001

[15] W. Shebansky. Blended Learning Adoption in an ESL Context: Obstacles and Guidelines. TESL Canada Journal, 35(1), 52-77, 2018. DOI:10.18806/tesl.v35i1.1284

[16] C. Procter. Blended Learning in Practice. Salford: University of Salford, 2003. ISBN: 0902896660

[17] D. Kaplanis. 5 Benefits of the Blended Learning Approach. 2013. https://www.talentlms com/blog/5-reasons-why-blended-learning-works/

[18] Y. Zhang. Influencing Factors of Students' Accepr . . Ice of Blended Learning Based on Cognitive Neural Network. NeuroQuantology, 16(5), 387 u95, 2018. DOI:10.14704/nq.2018.16.5.1305.

[19] J. Lencastre. Educação On-Line: desenhar um - 'irso híbrido centrado no estudante. In $\mathrm{H}$. Felício, C. Silva, A. Mariano, Dimensões do Procє isos Educacionais: Da Epistemologia à Profissionalidade Docente, 209-223, 2017. ('uritib=. Editora CRV.

[20] A. Littlejohn, C. Pegler. Preparing for Blendt___- '-arning. London: Routledge, 2007.

[21] A. Monteiro, J. Moreira, J. Lencastre. Blendr a ( ) Lı arning na Sociedade Digital. Santo Tirso: White Books, 2015.

[22] W. Kamalluarifin, F. Aniza, H. Jayabalan, M. ¿ '..., N. Bakar, S. Karib. Blended Learning: Satisfaction among Accounting Students in $\mathrm{JNI}^{-} \mathrm{EN}$ KSHAS. Global Business \& Management Research, 10(3), 547-557, 2018.

[23] C. Müller, M. Stahl, M. Alder, M. Müller. Lea nir y E fectiveness and Students' Perceptions in a Flexible Learning Course. European Journa - n, Distance and e-Learning, 21(2), 44-53, 2018. ISSN 1027-5207

[24] https://www.iscte-iul.pt/contents/iscteiul/about-י J J1/about-iscteiul in 08-05-2019.

[25] M. López-Pérez, M. Pérez-López, L. Rodriguez-Ariza. Blended learning in higher education: Students' perceptions and their relation outc smes. Computers \& Education, 56(3), 818-826, 2011. DOI:10.1016/j.compendu.2010.10.02:

N.B. this is the preprint version of the paper indicat $\neq a^{\prime}$, eluw.

T. Cardoso, F. Pestana, J. Pina (2019) A a SING A B-LEARNING TEACHING APPROACH AND STUDENTS' LEARNING PREFERENCES IN HIGHER E JUC $1 T I O N$, EDULEARN19 Proceedings, pp. 1000710012 .

Appears in:

EDULEARN19 Proceedings(browse)

Pages: $10007-10012$

Publication year: 2019

ISBN: 978-84-09-12031-4

ISSN: $2340-1117$

doi: 10.21125/edulearn.2019.2502

Conference name: 11th International Conference on Education and New Learning Technologies

Dates: 1-3 July, 2019

Location: Palmạ, Spain

https://library.iated.org/view/CARDOSO2019ASS

https://library.iated.org/publications/EDULEARN19/start/1500 